\title{
KOMUNIKASI ANTAR KARYAWAN ETNIS JAWA DAN TIONGHOA
}

\author{
Ferdika Tedjakusuma ${ }^{1}$, Eddy Madiono Sutanto ${ }^{1}$ \\ ${ }^{1}$ Program Manajemen Bisnis, Universitas Kristen Petra \\ Jalan Siwalankerto 121-131, Surabaya 60236, Indonesia \\ *Penulis Korespondensi; Email: dikatedjakusuma@gmail.com
}

\begin{abstract}
Abstrak
Penelitian ini bertujuan untuk mendeskripsikan tentang komunikasi horizontal antar karyawan berdasarkan aspek keragaman etnis, baik dari segi proses komunikasi antar karyawan, hambatan dalam lingkup komunikasi karyawan yang pernah/sedang terjadi dan upaya yang dilakukan oleh karyawan dalam mengatasi konflik komunikasi horizontal akibat dari hambatan tersebut. Teknik pengumpulan data menggunakan wawancara terstruktur dengan focus group discussion kepada tiga karyawan beretnis Jawa dan tiga karyawan beretnis Tionghoa. Wawancara dilakukan dengan membagi karyawan menjadi dua kelompok diskusi yang berbeda sesuai etnis karyawan untuk menjawab pertanyaan penelitian yang sama. Implikasi penelitian ini sesuai dengan hasil penelitian yang menyatakan bahwa keragaman etnis karyawan bukanlah aspek yang mempengaruhi kelangsungan komunikasi horizontal antar karyawan di lingkungan organisasi perusahaan.
\end{abstract}

Kata kunci: Karyawan, keragaman etnis, komunikasi horizontal, komunikasi antar karyawan

\begin{abstract}
This study was to describe the horizontal communication among employees with ethnic diversity in communication process, barriers of communication as well as efforts made by the employees in resolving horizontal communication conflicts. Data collection technique used focus group discussion of structured interviews to three Javanese employees and three Chinese employees. The interviews were done by dividing the employees into two discussion groups according to their ethnics to answer the same research questions. The implications of this study were in accordance with the results of the research which stated that employees' ethnic diversity didn't directly affect the continuity of horizontal communication among employees in the organization.
\end{abstract}

Keywords: Employee, ethnic diversity, horizontal communication, communication among employees

\section{Pendahuluan}

Tuntutan tenaga kerja yang multikultural saat ini memaksa perusahaan-perusahaan besar di Amerika untuk melakukan peningkatan jumlah karyawan dari berbagai macam etnis, ras dan negara (Griffin, 2004). Namun keseimbangan keragaman tenaga kerja hingga kini merupakan hal yang belum dapat dicapai oleh perusahaan-perusahaan Amerika. Tuntutan keragaman tenaga kerja kini telah menjadi salah satu dimensi penting di dalam lingkungan perusahaan atau organisasi bisnis, begitu pula di Indonesia. Salah satu objek dimensi keragaman tenaga kerja yang paling banyak ditemukan pada perusahaan-perusahaan di Indonesia adalah keragaman etnis antara etnis Tionghoa dan Jawa, mengingat hubungan antara kedua etnis ini sering digambarkan sebagai hubungan minoritas dan mayoritas (Warnaen, 2002).

Salah satu fenomena hubungan antar etnis tenaga kerja ditemukan pada penelitian yang dilakukan oleh Prasidyamurti (2013) di perusahaan Schlumberger yang menemukan bahwa karyawan di perusahaan Schlumberger ini kerap mengalami kendala akibat keragaman etnis dan budaya antar sesama karya- wan seperti adaptasi tenaga kerja, kendala bahasa dalam berkomunikasi, hingga kesalahpahaman komunikasi antar karyawan yang menyebabkan perselisihan. Fenomena lain mengenai stereotip antar etnis akibat keragaman tenaga kerja juga ditemukan pada penelitian lain yang dilakukan oleh Christiana (2005) di PT Lokaniaga Adipermata Semarang yang menemukan adanya anggapan bahwa karyawan etnis Tionghoa dinilai lebih berkualitas dan ambisius dibandingkan dengan karyawan beretnis Jawa, sehingga karyawan beretnis Tionghoa lebih memungkinkan menduduki posisi penting di dalam perusahaan.

Keragaman tenaga kerja pada dasarnya jika dapat dikelola dengan bijaksana akan melahirkan suatu potensi yang dinamis dan integratif (Kusumah, Marjanto, Rostiyati \& Ernayanti, 2007). Salah satunya dengan cara membangun komunikasi interpersonal yang efektif. Komunikasi dapat dikatakan sebagai bentuk interaksi sosial dalam perusahaan yang merupakan jembatan antara karyawan dengan karyawan maupun karyawan dengan pimpinan (Effendy, 2007). Namun membangun komunikasi interpersonal yang efektif di lingkungan kerja dengan adanya keragaman tenaga kerja merupakan hal yang tidak mudah. 
Mathis dan Jackson (2000) mengatakan bahwa keragaman tenaga kerja dalam suatu perusahaan tidak dapat dipungkiri memiliki sisi negatif, seperti kesulitan untuk berkomunikasi serta meningkatnya ketegangan dan konflik di tempat kerja. Keragaman juga membawa perbedaan dalam gaya berkomunikasi, sehingga seringkali menciptakan kesalahpahaman (Yoshida, 2002).

Penelitian ini dilakukan di salah satu perusahaan manufaktur di Surabaya, Indonesia, sebab pada perusahaan manufaktur ditemukan intensitas interaksi karyawan yang lebih tinggi dengan adanya aspek perbedaan etnis karyawan yang lebih beragam. Penelitian ini bertujuan untuk menganalisis secara deskriptif proses komunikasi horizontal antar karyawan dengan adanya keragaman etnis. Komunikasi yang dimaksud pada penelitian ini adalah komunikasi interpersonal secara horizontal antar sesama karyawan yang efektif, baik dari segi verbal vokal maupun non verbal. Bentuk-bentuk komunikasi horizontal karyawan yang efektif pada penelitian ini mengacu pada teori Suranto (2005) yaitu dari segi pemahaman pesan, suasana lingkungan, hubungan interpersonal dan respon tindakan. Perbedaan etnis yang dikategorikan dalam analisis penelitian ini adalah keragaman etnis antara etnis Tionghoa dan etnis Jawa sebagai dua etnis yang mayoritas berada pada perusahaan. Selain itu, rumusan masalah pada penelitian ini juga untuk menganalisis secara deskriptif apa saja hambatan-hambatan komunikasi horizontal antar karyawan. Menurut Suranto (2005), hambatan komunikasi horizontal yaitu hambatan sosiologis, psikologis, semantis dan mekanis yang sedang/pernah terjadi akibat adanya keragaman etnis. Penelitian ini juga untuk menganalisis upaya-upaya karyawan dalam mengatasi konflik komunikasi horizontal di dalam perusahaan seperti menghindar, menurut, berkompromi, mendominasi, atau mengintegrasikan konflik akibat hambatan-hambatan tersebut.

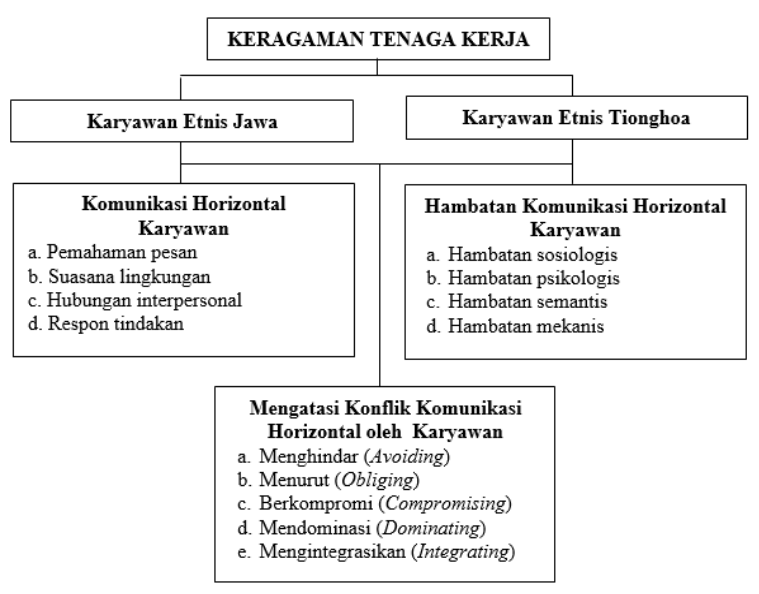

\section{Gambar 1. Kerangka Konseptual}

Sumber: Suranto (2005); Ting-Toomey dan Chung (2005)
Penelitian ini akan menganalisis dan mendeskripsikan keragaman tenaga kerja dari segi komunikasi karyawan berdasarkan indikator komunikasi, hambatan komunikasi karyawan dan upaya dalam mengatasi konflik komunikasi horizontal.

\section{Metode Penelitian}

Penelitian ini menggunakan metode deskriptif dengan pendekatan kualitatif untuk memahami fenomena apa yang dialami oleh subjek penelitian misalnya perilaku, persepsi, motivasi, tindakan, dan lain-lain, dengan cara deskripsikan dalam bentuk kata-kata dan bahasa pada suatu konteks khusus yang alamiah serta dengan memanfaatkan berbagai metode ilmiah (Moleong dalam Kuntjojo, 2009). Penelitian ini akan mendeskripsikan tentang komunikasi horizontal antara karyawan etnis Tionghoa dan etnis Jawa, baik dari segi proses komunikasi antar karyawan, hambatan dalam lingkup komunikasi karyawan yang pernah/ sedang terjadi dan upaya yang dilakukan oleh karyawan dalam mengatasi konflik komunikasi horizontal yang ada. Hal ini dilakukan dengan cara wawancara langsung menggunakan model focus group discussion, sehingga sudut pandang dan pendapat karyawan merupakan fokus utama dari penelitian ini.

Teknik sampling yang digunakan adalah non probabilitas yang berjenis purposive sampling yaitu dengan memilih subjek penelitian berdasarkan kriteria spesifik yang telah ditetapkan peneliti (Kuntjojo, 2009). Narasumber utama pada penelitian ini adalah para karyawan yang bekerja di kantor perusahaaan, yang terdiri dari tiga orang karyawan beretnis Jawa dan tiga orang karyawan beretnis Tionghoa. Kriteria narasumber yang akan menjadi subjek penelitian ilmiah ini adalah karyawan kantor yang telah bekerja selama minimal dua tahun, memiliki jumlah rata-rata gaji yang sama, serta jabatan atau kedudukkan yang sama.

Penetapan narasumber utama pada penelitian ini dilakukan bersama pihak manajer Human Resource sejak satu minggu sebelum proses wawancara dan pengumpulan data dilakukan. Penetapan narasumber utama dilakukan melalui pemilihan langsung oleh pihak manajer Human Resource berdasarkan penilaian secara subjektif, biodata karyawan yang dimiliki oleh pihak manajer Human Resource dan pengakuan langsung para karyawan selaku narasumber utama pada penelitian ini.

Sumber data primer di dalam penelitian ini adalah pendapat, suara dan sudut pandang karyawan mengenai topik penelitian dari hasil wawancara langsung dengan enam orang karyawan menggunakan model focus group discussion. Sumber data sekunder yang digunakan di dalam penelitian ini ada- 
lah buku profil perusahaan (company profile) dan dokumen-dokumen mengenai karyawan yang didapatkan pada saat melakukan survei awal.

Teknik pengumpulan data yang dilakukan pada penelitian ini menggunakan teknik non tes berbentuk wawancara yang bertujuan untuk mendapatkan datadata penelitian yang dilakukan pada kantor perusahaan. Metode wawancara yang dilakukan adalah wawancara terstruktur terhadap pihak-pihak yang akan ditentukan sebagai subjek penelitian. Focus group discussion digunakan dengan cara membagi para narasumber ke dalam kelompok-kelompok diskusi kecil sehingga dalam proses wawancara dapat memunculkan ide-ide, informasi dan sudut pandang dari para narasumber secara lebih bebas dan terbuka. Focus group discussion adalah bentuk diskusi yang didesain untuk memunculkan informasi mengenai keinginan, kebutuhan, sudut pandang, kepercayaan dan pengalaman yang dikehendaki oleh peserta (Paramita \& Kristiana, 2013).

Pertanyaan wawancara yang sama diajukan kepada dua kelompok narasumber di dalam ruangan khusus selama kurang lebih dua jam dan berlangsung selama dua hari, yaitu kelompok narasumber pertama pada hari pertama dan kelompok narasumber kedua pada hari kedua. Proses wawancara berlangsung dengan suasana yang santai dan informal, sehingga bertujuan untuk dapat menghasilkan jawaban dari pertanyaan-pertanyaan penelitian secara terbuka, jujur, bebas, berdasarkan sudut pandang dan pengalaman para karyawan secara pribadi. Proses wawancara dengan model focus group discussion pada narasumber yang memiliki perbedaan etnis ini telah diatur sejak awal agar dilakukan secara terpisah, yakni kelompok pertama beranggotakan karyawan beretnis Jawa dan kelompok kedua beranggotakan karyawan beretnis Tionghoa. Uji validitas triangulasi narasumber dilakukan dengan memilih tiga narasumber karyawan beretnis Jawa dan tiga narasumber karyawan beretnis Tionghoa sesuai kriteria yang telah ditentukan. Langkah berikutnya adalah membagi tiga orang karyawan beretnis Jawa dan tiga orang karyawan beretnis Tionghoa menjadi dua kelompok diskusi sesuai dengan perbedaan etnis mereka. Pemisahan kelompok narasumber wawancara ini dilakukan agar karyawan dapat bercerita dan menjawab pertanyaan-pertanyaan penelitian secara bebas tanpa adanya tekanan dari karyawan yang berbeda etnis.

Pertanyaan-pertanyaan penelitian yang diajukan kepada dua kelompok narasumber ini sama, namun dilakukan di ruangan/lokasi dan hari yang berbeda. Pertanyaan penelitian meliputi bagaimana proses interaksi komunikasi yang terjadi antar sesama karyawan di lingkungan kantor, tingginya intensitas komunikasi horizontal yang terjadi, apakah perbedaan-perbedaan yang dirasakan oleh karyawan saat menjalin komunikasi dengan karyawan yang berbeda etnis, hambatan-hambatan dan konflik seperti apa yang kerap terjadi dalam menjalin hubungan dengan karyawan yang berbeda etnis, serta bagaimana upaya karyawan dalam mengatasi konflik komunikasi dengan karyawan lain yang berbeda etnis sehingga dapat tetap menjaga hubungan komunikasi yang efektif.

\section{Hasil Penelitian dan Pembahasan}

\section{Proses Komunikasi Horizontal Karyawan}

Proses komunikasi horizontal yang terjadi antara karyawan beretnis Jawa dan karyawan beretnis Tionghoa ditemukan bahwa tidak dibutuhkan prosedur khusus dalam melakukan komunikasi horizontal, sehingga berlangsung secara bebas dan terbuka. Sesuai dengan Pakpahan (2010), komunikasi antara karyawan beretnis Jawa dan karyawan beretnis Tionghoa dilakukan langsung oleh para karyawan dalam bentuk hubungan interpersonal secara bebas dan terbuka. Karyawan beretnis Jawa dan karyawan beretnis Tionghoa membuktikan bahwa proses komunikasi horizontal yang dilakukan melalui hubungan interpersonal sejauh ini dapat berlangsung dengan baik. Komunikasi berjenis vertikal hanya akan terjadi apabila komunikasi yang dilakukan merupakan pengambilan suatu keputusan atau untuk mendiskusikan permasalahan internal di dalam divisi yang memiliki pengaruh pada kinerja karyawan jangka panjang. Hasil pernyataan analisis ini didukung dari hasil wawancara dengan dua kelompok narasumber yang secara sepakat mendeskripsikan proses komunikasi horizontal yang berlangsung di lingkungan organisasi.

Berdasarkan hasil wawancara dengan narasumber beretnis Jawa berinisial T.T. yang mengungkapkan bahwa, "Jika hanya berkomunikasi biasa dengan sesama karyawan ya kita biasanya langsung bicara atau telepon, tetapi jika ada masalah yang benarbenar rumit atau untuk pengambilan suatu keputusan baru kita komunikasikan dahulu dengan supervisor", yang kemudian disepakati oleh para narasumber beretnis Jawa yang lainnya. Hal serupa juga diungkapkan oleh narasumber beretnis Tionghoa berinisial N.N. dan C.T. yang mengatakan bahwa dalam berkomunikasi dengan sesama karyawan dapat dilakukan secara langsung dan prosedur berkomunikasi melalui pihak manajerial atau supervisor hanya dilakukan untuk pengambilan suatu keputusan yang mempengaruhi divisi. Proses komunikasi horizontal antara karyawan dapat berlangsung dengan baik, sebab ditemukan ada- 
nya peranan pihak manajerial yang turut memfasilitasi dan menciptakan iklim komunikasi yang baik. Pihak manajerial memfasilitasi komunikasi horizontal karyawan agar dapat berlangsung dengan efektif, seperti menerapkan aturan pergantian tempat duduk karyawan, ruang lingkup kerja yang terbuka, media komunikasi bersifat elektronik yang memadai, serta iklim organisasi yang dibangun bersifat kekeluargaan. Hal ini sesuai dengan hasil temuan pada penelitian sebelumnya oleh Wijaya (2014) di PT Gramitrama Jaya Steel yang juga menemukan proses komunikasi antar sesama karyawan berbeda etnis dapat berlangsung dengan baik akibat adanya peranan pihak manajerial yang turut memfasilitasinya.

Model komunikasi interaktif yang terjadi antara karyawan beretnis Jawa dan beretnis Tionghoa terbukti menciptakan proses komunikasi horizontal karyawan di dalam perusahaan dapat berlangsung dengan baik. Hal ini sesuai dengan Kohler (dalam Wursanto, 2003). Komunikasi interaktif yang terjadi disebabkan oleh tingginya intensitas komunikasi horizontal antara karyawan beretnis Jawa dan karyawan beretnis Tionghoa, yang ditemukan baik dalam bentuk komunikasi verbal vokal maupun komunikasi non verbal seperti senyuman dan sapaan. Narasumber karyawan beretnis Jawa berinisial S.S. mengatakan,

"Kalau saya rasa sering ya karena ya itu, setiap hari bertemu. Sehari-hari kita harus berkomunikasi dengan mereka karena kita kerja juga saling berhubungan, jadi setiap hari pasti ada saling berkomunikasi. Selain itu, di luar juga kita sering kumpul-kumpul bersama."

Hal tersebut juga diakui oleh para narasumber karyawan beretnis Jawa yang lain berinisial P.T. dan T.T. yang menambahkan bahwa seringnya komunikasi yang terjadi antar sesama karyawan dikarenakan adanya tuntutan dan keterkaitan pekerjaan antar setiap divisi. Hubungan komunikasi horizontal yang terjadi ini pun diakui pula oleh para narasumber karyawan beretnis Tionghoa bahwa tidak pernah terjadi masalah akibat adanya keragaman etnis. Salah satu narasumber karyawan beretnis Tionghoa berinisial S.L. mengatakan bahwa,

"Jadi begini, masalahnya itu bukan karena kita beda etnis, tapi keterikatan antar divisi. Kita gak melihat warna kulit atau suku bangsanya. Antar divisi itu kan di sini saling terkait, jadi tiap hari pasti bicara, dan kalau sudah begitu ya langsung saja bicara kita ada perlu apa atau apa. Kalau kita di sini gak mau bicara hanya karena beda etnis ya kapan selesainya pekerjaan kita, orang pekerjaannya saling berhubungan antar divisi”.
Pernyataan narasumber S.S. dan S.L. ini disepakati pula oleh para narasumber karyawan yang lain. Ini menunjukkan bahwa proses komunikasi horizontal yang berlangsung dapat terjalin dengan baik tanpa adanya masalah yang diakibatkan oleh faktor keragaman etnis.

\section{Bentuk Komunikasi Horizontal Karyawan}

\section{Pemahaman Pesan Komunikasi}

Menurut Suranto (2005), bentuk pemahaman pesan komunikasi adalah kemampuan dalam memahami pesan secara cermat sebagaimana dimaksudkan oleh komunikator. Kemampuan karyawan beretnis Jawa dan karyawan beretnis Tionghoa dalam memahami pesan komunikasi horizontal tergolong tinggi, namun terkadang masih terjadi adanya kesalahpahaman komunikasi baik dari segi penyaluran pesan maupun penerimaan pesan komunikasi antar karyawan, terutama komunikasi mengenai jabaran pekerjaan karyawan maupun dari segi bahasa yang digunakan dalam berkomunikasi. Salah satu narasumber beretnis Jawa yang bernisial P.T. mengungkapkan, "Dari segi bahasanya kita saja. Seperti kita orang Surabaya etnis Jawa jika berbicara kan menggunakan bahasa Jawa ngoko yang kental, sedangkan yang berbeda etnis kan terkadang tidak mengerti. Jadi terkadang bisa miss communication biasanya." Narasumber karyawan beretnis Tionghoa yang berinisial N.N. dan C.T. mengungkapkan bahwa hal yang rentan menjadi kesalahpahaman adalah komunikasi mengenai jabaran pekerjaan. Pernyataan tersebut didasari oleh salah satu narasumber beretnis Tionghoa dengan inisial S.L. yang mengatakan,

"Kalau menurut saya tidak ada kesulitan khusus begitu ya meskipun berbicara dengan yang berbeda etnis. Ya itu lagi, menurut saya kembali lagi, karakter orangnya. Seperti misalnya di sini ada yang bicara itu intonasinya keras, akhirnya orang yang tidak mengerti menjadi ikut terpancing, lalu marah. Kesulitannya justru memahami karakter tiap-tiap orang yang berbeda-beda ini yang sulit, bukan dari segi Jawa atau Tionghoanya. Karena tiap orang itu punya karakter yang tidak sama, yang belum tentu bisa diterima semua orang, meskipun etnisnya sama".

Kesalahpahaman dalam memahami komunikasi jabaran pekerjaan oleh karyawan beretnis Jawa dan karyawan beretnis Tionghoa ini terjadi karena:

a. Ketidakjelasan informasi atau pesan komunikasi yang disampaikan. 
Terjadi ketidakjelasan alur kronologis komunikasi dari siapa kepada siapa dan apa tujuan dari informasi tersebut disampaikan. Pernyataan analisis deskripsi ini didukung oleh fakta yang diungkapkan oleh narasumber bahwa dalam melakukan komunikasi horizontal, masih terjadi tidak adanya kejelasan informasi dari pesan yang disampaikan, sehingga terjadi kesalahpahaman.

b. Perbedaan karakter personal karyawan dalam berkomunikasi.

Karyawan yang belum sepenuhnya dapat beradaptasi dengan karakter karyawan lain yang memiliki gaya komunikasi berintonasi tinggi dan keras sehingga terkesan emosional, serta karakter karyawan yang biasa berkomunikasi dengan bahasa yang singkat dan cepat. Pernyataan analisis deskripsi ini didukung pula oleh fakta yang ditemukan ketika proses wawancara narasumber berlangsung dan hasil observasi singkat yang menemukan adanya perbedaan karakter personal karyawan yang beragam.

c. Kebiasaan penggunaan bahasa dalam berkomunikasi.

Perbedaan kosa kata antara karyawan beretnis Jawa dengan logat bahasa Jawa yang kental, serta karyawan beretnis Tionghoa yang sesekali menggunakan bahasa Mandarin dalam berkomunikasi terutama dalam menyebutkan nominal angka menjadi salah satu penyebab kesalahpahaman.

Cara yang dilakukan oleh karyawan beretnis Jawa dan karyawan beretnis Tionghoa dalam beradaptasi dengan keragaman karakter karyawan dan menemukan kesepahaman dalam berkomunikasi sesuai dengan penelitian Kurniawan (2011). Menurut Kurniawan yang meneliti Kompetensi Komunikasi Antar Budaya Anggota Perkumpulan Masyarakat Surakarta Etnis Tionghoa dan Jawa, pembauran dan pendekatan interpersonal terjadi tanpa melihat perbedaan etnis. Pendekatan interpersonal dilakukan oleh karyawan beretnis Jawa untuk mengenali karakter karyawan yang berbeda etnis maupun yang beretnis sama. Karyawan beretnis Tionghoa mereka tidak segan melakukan komunikasi ulang dengan karyawan yang bersangkutan demi menemukan kejelasan informasi dan mencapai kesepahaman komunikasi.

\section{Suasana Lingkungan dalam Berkomunikasi}

Suasana lingkungan yang tercipta saat menjalin hubungan komunikasi antara karyawan beretnis Jawa dan karyawan beretnis Tionghoa tidak dipengaruhi oleh keragaman etnis karyawan, melainkan dipengaruhi oleh keragaman tingkat kesibukan aktivitas karyawan. Secara bertahap, suasana lingkungan dalam berkomunikasi dapat terbangun, baik dengan adanya peningkatan hubungan interpersonal antar karyawan dengan karyawan beretnis Jawa maupun karyawan beretnis Tionghoa. Hal itu disebabkan oleh tingginya intensitas komunikasi horizontal yang terjadi antar sesama karyawan dan iklim lingkungan perusahaan yang mendukung, baik dari segi tata letak ruang kantor yang membuat setiap karyawannya mudah bertemu langsung secara tatap muka maupun iklim komunikasi di dalam lingkungan perusahaan yang bersifat kekeluargaan. Hasil analisis ini sesuai dengan penelitian sebelumnya oleh Marcyola (2013) mengenai Iklim Komunikasi Organisasi dan Kinerja Karyawan di Bank Bukopin Cabang Medan yang menunjukkan bahwa iklim dan suasana komunikasi di dalam suatu perusahaan mempengaruhi cara hidup individu dan tingkat relasi interpersonal di dalam perusahaan.

Di sisi lain, suasana lingkungan dalam berkomunikasi antar karyawan terkadang ditemukan adanya ketidaknyamanan yang diakibatkan oleh keragaman karakter personal karyawan, konteks komunikasi mengenai masalah personal dan tingkat kesibukan aktivitas karyawan saat komunikasi horizontal berlangsung. Karakter karyawan dengan pembawaan emosional yang buruk menyebabkan pesan yang diterima kerap menjadi rancu dan berpotensi menyebabkan kesalahpahaman. Berkomunikasi dengan karyawan yang sedang berfokus dengan aktivitas pekerjaannya menyebabkan respon terhadap pesan komunikasi menjadi lambat dan komunikasi horizontal menjadi tidak efektif. Berkomunikasi mengenai hal pribadi juga dianggap oleh karyawan merupakan hal yang tidak etis untuk dibicarakan di lingkup internal perusahaan. Berdasarkan temuan data dapat disimpulkan bahwa keragaman karakter personal karyawan, konteks komunikasi dan tingkat aktivitas karyawan secara fisik lebih banyak mempengaruhi suasana lingkungan dalam berkomunikasi daripada keragaman etnis karyawan itu sendiri. Hal ini berbeda dengan penelitian sebelumnya oleh Prasidyamurti (2013) yang berpendapat bahwa keragaman etnis karyawan merupakan hal yang menyebabkan ketidaknyamanan pada iklim komunikasi organisasi.

Hubungan Interpersonal Komunikator dan Komunikan

Hubungan interpersonal yang terjalin antara komunikator dan komunikan pada karyawan beretnis Jawa dan karyawan beretnis Tionghoa menunjukkan adanya peningkatan, namun dengan persepsi hubung- 
an yang berbeda. Karyawan beretnis Jawa merasakan bahwa peningkatan hubungan interpersonal dalam melakukan komunikasi horizontal dengan karyawan beretnis Tionghoa hanya terbatas pada hubungan profesionalisme dan kerjasama di bidang pekerjaan, sedangkan karyawan beretnis Tionghoa merasakan bahwa peningkatan hubungan interpersonal dalam melakukan komunikasi horizontal dengan karyawan beretnis Jawa dapat terjalin hingga pada lingkup persahabatan, walaupun karyawan-karyawan beretnis Tionghoa merasakan adanya sikap yang kurang terbuka dari karyawan beretnis Jawa. Salah satu narasumber karyawan beretnis Tionghoa berinisial S.L. mengatakan,

"Kalau saya merasa tidak ada beda. Saya menganggap mereka yang berbeda etnis atau suku itu ya sama, biasa saja. Mungkin dari mereka yang menganggap kita 'luar biasa', entah itu kenapa. Jika saya tidak pernah menilai mereka berbeda begitu, justru biasanya yang saya tangkap dari mereka itu anggapan kalau yang berkulit gelap menghadapi kita yang berkulit putih itu agak takut begitu ya. Akhirnya penyampaian mereka ke kita yang jadi agak-agak malu-malu sungkan begitu. Padahal dari kita ya menganggap biasa-biasa saja".

Pernyataan tersebut disepakati pula oleh narasumber beretnis Tionghoa yang lainnya berinisial N.N. dan C.T. yang merasakan hal serupa.

Karyawan beretnis Jawa, para narasumber sepakat mengungkapkan bahwa peningkatan hubungan interpersonal dengan karyawan berbeda etnis hanya terjalin sebatas hubungan kerja saja. Hal tersebut diungkapkan oleh salah satu narasumber karyawan beretnis Jawa berinisial S.S., "Saya merasa jika dikatakan meningkat ya benar ada peningkatan, tetapi meningkatnya dalam hubungan kerja saja, karena di luar itu saya rasa sudah bukan urusan kita ya."

Perbedaan persepsi hubungan interpersonal yang terjalin dalam melakukan komunikasi horizontal pada karyawan beretnis Jawa ini disebabkan oleh karakteristik dasar masyarakat beretnis Jawa yang sesuai dengan penelitian sebelumnya (Setyowati, 2013) yaitu segan, sopan santun dan tidak mudah terbuka. Hal tersebut menyebabkan karyawan beretnis Jawa cenderung menciptakan batasan dalam berkomunikasi dan menjalin hubungan interpersonal dengan orang lain. Perbedaan persepsi hubungan interpersonal pada karyawan beretnis Tionghoa ini juga tidak terlepas dari karakteristik masyarakat etnis Tionghoa di Indonesia pada umumnya, sesuai pada penelitian Yvone, Krasono dan Suprajitno (2014) yang menjelaskan bahwa salah satu karakteristik etnis Tionghoa adalah mudah beradaptasi dengan orang-orang baru di sekitarnya sehingga lebih mudah bagi mereka dalam menjalin persahabatan. Karyawan beretnis Jawa memiliki karakteristik yang lebih menjaga etika dan sikap saat berkomunikasi, sehingga lebih lambat dalam menjalin hubungan interpersonal dengan sesama karyawan. karyawan beretnis Tionghoa yang memiliki karakteristik lebih terbuka dan bersemangat dalam melakukan komunikasi lebih cepat menjalin hubungan interpersonal dengan sesama karyawan yang lain.

\section{Respon Tindakan terhadap Pesan yang Dikomuni-} kasikan

Respon tindakan karyawan terhadap pesan komunikasi horizontal baik oleh karyawan beretnis Jawa maupun karyawan beretnis Tionghoa dari hasil temuan data menunjukkan bentuk respon tindakan yang sama tanpa adanya perbedaan yang didasari oleh keragaman etnis. Respon tindakan karyawan terbagi menjadi dua jenis yaitu respon positif dan respon negatif, disebabkan oleh tingkat aktivitas karyawan secara fisik:

a. Respon positif.

Bentuk respon tindakan positif berupa sikap non verbal terhadap komunikasi horizontal yaitu selalu memberikan perhatian dengan melihat mata lawan bicaranya dan mau bertatap muka pada saat komunikasi berlangsung. Respon tindakan yang positif berupa verbal vokal adalah memberikan pertanyaan-pertanyaan dan pernyataan-pernyataan sebagai umpan balik atas isi pesan dari komunikasi horizontal yang telah berlangsung.

b. Respon negatif.

Bentuk respon tindakan negatif terhadap komunikasi horizontal hanya terjadi pada saat perhatian karyawan tersebut terfokus pada aktivitas pekerjaannya yang tinggi, seperti tidak melihat lawan bicara saat komunikasi horizontal berlangsung karena lebih berfokus pada pekerjaannya dan hanya memberikan respon yang lambat berupa kata-kata singkat.

Respon tindakan karyawan terhadap komunikasi horizontal yang terjadi secara bebas tidak menunjukkan perbedaan yang disebabkan oleh keragaman etnis karyawan. Hasil analisis ini bertolak belakang dengan penelitian sebelumnya oleh Palinggi (2013) yang mengatakan bahwa keragaman etnis karyawan akan mengakibatkan komunikasi antar karyawan mengarah pada sense of community (Marger, 2006) akibat adanya perbedaan respon karyawan terhadap komunikasi horizontal yang lebih mengutamakan karyawan dengan latar belakang etnis yang sama. 


\section{Hambatan Komunikasi Horizontal Karyawan}

\section{Hambatan Sosiologis}

Komunikasi karyawan secara horizontal antara karyawan beretnis Jawa dan karyawan beretnis Tionghoa tidak ditemukan adanya konflik komunikasi horizontal yang diakibatkan oleh hambatan sosiologis. Hal itu disebabkan oleh iklim komunikasi perusahaan yang sejak awal telah bersifat kekeluargaan. Salah satu hal yang menekan dampak negatif akibat hambatan sosiologis adalah budaya saling menyapa yang dilakukan oleh setiap karyawan kepada karyawan lain yang ditemui di lingkungan perusahaan, serta menjaga hubungan antar karyawan dengan tetap melakukan komunikasi horizontal secara rutin di lingkungan perusahaan.

Lebih lanjut, hambatan sosiologis dari segi perbedaan agama juga tidak ditemukan di dalam hubungan antar karyawan. Fakta menunjukkan bahwa perusahaan tidak menerapkan nilai-nilai keragamaan baik di dalam sistem manajerial, visi misi perusahaan, serta tidak meletakkan simbol-simbol agama di dalam lingkungan perusahaan. Hambatan sosiologis dari segi perbedaan tingkat pendidikan karyawan juga tidak ditemukan pada karyawan dalam melakukan komunikasi secara horizontal, sebab seluruh karyawan telah bergelar Sarjana Strata Satu, sehingga secara umum karyawan beretnis Jawa dan karyawan beretnis Tionghoa memiliki tingkat pemahaman intelektual yang setara.

Analisis hambatan sosiologis pada komunikasi horizontal dengan adanya keragaman etnis karyawan ini berbeda dengan penelitian sebelumnya oleh Christiana (2005) yang menemukan bahwa terdapat hambatan sosiologis dari segi tingkat pendidikan pada komunikasi horizontal antar karyawan yang berbeda etnis, sehingga menciptakan stereotip karyawan beretnis Tionghoa lebih cerdas daripada karyawan beretnis Jawa dan mengakibatkan komunikasi horizontal dengan karyawan beretnis Jawa terjalin dengan buruk.

\section{Hambatan psikologis}

Komunikasi horizontal pada karyawan beretnis Jawa dan karyawan beretnis Tionghoa ditemukan adanya hambatan psikologis, yaitu dari segi perbedaan karakter karyawan dalam berkomunikasi. Berdasarkan hasil penelitian, ditemukan adanya karakter karyawan yang keras dan mudah terpancing amarah pada saat menerima kritik atau saran dari karyawan lain, sehingga berkomunikasi dengan karyawan tersebut lebih berpotensi menimbulkan konflik dalam berkomunikasi. Berdasarkan hasil wawancara, ditemukan salah satu contoh kasus yang pernah terjadi adalah ter- dapat salah seorang karyawan dengan karakter yang emosional mendapatkan kritik dari karyawan lain pada saat forum rapat divisi yang ternyata membuat karyawan tersebut marah dan akhirnya mengundurkan diri dua minggu kemudian. Di sisi lain, ditemukan pula karakter karyawan yang kerap membawa permasalahan pribadi ke dalam komunikasi internal perusahaan serta karakter dengan gaya bicara yang singkat dan cepat, sehingga komunikasi antar karyawan terkadang menjadi tidak efektif dan menimbulkan kesalahpahaman. Hambatan psikologis yang terjadi pada komunikasi horizontal karyawan ini sesuai dengan hasil penelitian terdahulu pada PT Dinamika Anak Muda Nasional (Meiliana, 2014) yang menemukan bahwa karakter dan suasana hati karyawan turut mempengaruhi komunikasi horizontal antar karyawan dan menentukan kinerja karyawan di lingkungan organisasi.

\section{Hambatan Semantis}

Hambatan semantis dari segi penggunaan bahasa ditemukan pada komunikasi horizontal antara karyawan beretnis Jawa dan karyawan beretnis Tionghoa. Karyawan beretnis Jawa terbiasa menggunakan bahasa Jawa Ngoko dalam berkomunikasi sehari-hari sebagai salah satu nilai budayanya dan karyawan beretnis Tionghoa yang terkadang menggunakan bahasa Mandarin sebagai bahasa leluhurnya dalam berbicara, terutama mengenai nominal angka. Penggunaan bahasa komunikasi yang berbeda ini terkadang terjadi saat komunikasi horizontal berlangsung, sehingga mengakibatkan kesalahpahaman komunikasi dan berpotensi menimbulkan prasangka. Salah satu contoh kasus yang diungkapkan oleh salah satu narasumber adalah karyawan beretnis Tionghoa yang tidak jarang berkomunikasi dengan menggunakan bahasa Mandarin mengenai nominal uang seperti "cem ban" (sepuluh ribu), "no diao" (dua juta), dan sebagainya sehingga kerap kali membuat karyawan lain yang beretnis Jawa kebingungan. Pihak manajerial saat ini telah menerapkan aturan yang mengharuskan seluruh personal di dalam perusahaan untuk menggunakan Bahasa Indonesia dalam berkomunikasi di lingkungan perusahaan. Akan tetapi, penerapan aturan tersebut hingga saat ini belum dapat mencapai hasil yang optimal.

Sesuai dengan penelitian sebelumnya oleh Prasidyamurti (2013) di perusahaan Schlumberger juga ditemukan ketidakefektifan komunikasi horizontal antara karyawan yang berbeda etnis dikarenakan adanya perbedaan penggunaan bahasa, analisis hambatan semantis pada komunikasi horizontal antara karyawan dengan keragaman etnis ini juga terjadi. 


\section{Hambatan Mekanis}

Hambatan komunikasi horizontal dari segi mekanis tidak ditemukan pada komunikasi antara karyawan beretnis Jawa dan karyawan beretnis Tionghoa. Pihak manajerial menerapkan sistem kerja di lingkungan perusahaan seperti posisi tempat duduk karyawan yang berubah-ubah setiap bulan agar dapat saling berinteraksi dengan karyawan yang berbeda, ruang kerja yang tanpa adanya pembatas meja, serta struktur kerja yang mengharuskan karyawan melakukan interaksi komunikasi. Hal tersebut mengakibatkan komunikasi horizontal antar karyawan berbeda etnis dapat terjalin dengan baik. Selain itu, fasilitas media komunikasi seperti saluran internal telepon di setiap meja kerja karyawan dan fasilitas Wi-Fi yang lengkap telah mendukung berlangsungnya komunikasi antar karyawan di lingkungan kantor dengan baik.

\section{Mengatasi Konflik Komunikasi Horizontal oleh Karyawan}

Upaya-upaya karyawan beretnis Jawa dan karyawan beretnis Tionghoa dalam mengatasi konflik komunikasi horizontal antar sesama karyawan menunjukkan kesesuaian dengan teori dari TingToomey dan Chung (2005). Karyawan beretnis Jawa pertama-tama akan berupaya berkompromi (compromising) dalam mengatasi konflik komunikasi horizontal antar sesama karyawan, dengan cara mencari tahu apa yang menjadi sumber konflik komunikasi dan melakukan komunikasi ulang dengan karyawan yang bersangkutan untuk menemukan solusi terbaik atas konflik komunikasi horizontal yang terjadi. Tindakan kedua yang dilakukan oleh karyawan beretnis Jawa apabila upaya compromising tidak menemukan solusi adalah dengan mengintegrasikan (integrating) apa yang menjadi maksud dari tiap-tiap karyawan demi mencapai win-win solution.

Hal serupa juga dilakukan oleh karyawan beretnis Tionghoa dalam mengatasi konflik komunikasi horizontal antar sesama karyawan. Berkompromi (compromising) merupakan tindakan pertama yang akan dilakukan untuk menemukan solusi atas konflik komunikasi horizontal yang terjadi. Perbedaan dengan karyawan beretnis Jawa, apabila upaya compromising tidak menghasilkan solusi maka karyawan beretnis Tionghoa memiliki kecenderungan untuk bersikap menghindari (avoiding) konflik komunikasi horizontal dengan membiarkan konflik tersebut terselesaikan dengan sendirinya atau sekadar memberikan senyuman sebagai bentuk komunikasi non verbal kepada karyawan yang bersangkutan.

\section{Pembahasan}

Proses komunikasi horizontal antar sesama karyawan yang baik di dalam lingkungan organisasi dapat meningkatkan hubungan kerjasama antar karyawan, penyampaian koordinasi dan informasi tugas, serta hubungan interpersonal antar karyawan (Pakpahan, 2010). Penerapan sistem manajemen di dalam lingkungan perusahaan dapat berjalan secara efektif apabila komunikasi horizontal di antara karyawan juga berjalan dengan efektif. Kesalahpahaman dalam melakukan koordinasi tugas hingga konflik yang dapat menghambat kerjasama tim dapat dihindari dengan proses komunikasi antar karyawan di dalam perusahaan sehingga komunikasi berjalan dengan baik. Lattimore, Baskin, Heiman, dan Toth (2010) menjelaskan bahwa komunikasi horizontal yang baik di dalam suatu perusahaan dapat meningkatkan efektivitas dan efisiensi manajemen perusahaan, memelihara komunikasi internal di dalam perusahaan serta mengembangkan kualitas sumber daya manusia.

Proses komunikasi horizontal yang terjadi antara karyawan beretnis Jawa dan karyawan beretnis Tionghoa telah berlangsung dengan baik. Sikap prasangka dan stereotip terhadap keragaman etnis tidak ditemukan pada komunikasi horizontal dengan adanya kergaman etnis karyawan ini, sehingga komunikasi dan kerjasama di lingkungan perusahaan dapat berlangsung dengan efektif tanpa ditemukan adanya sikap curiga atau gap (membentuk kelompokkelompok kecil) antar karyawan yang berbeda etnis. Proses komunikasi horizontal antar karyawan berlangsung secara baik sebab adanya peranan campur tangan pihak manajerial yang secara khusus mengatur dengan sistem seperti posisi tempat duduk karyawan yang berubah-ubah di setiap bulannya agar setiap karyawan dapat saling berinteraksi dengan karyawan yang berbeda, ruang kerja yang tanpa adanya pembatas, struktur kerja yang mengharuskan karyawan melakukan interaksi komunikasi, serta budaya organisasi yang dibangun bersifat kekeluargaan. Meskipun demikian, terkadang masih ditemukan adanya hambatan-hambatan komunikasi yang berpotensi menyebabkan komunikasi horizontal berujung pada kesalahpahaman dan konflik. Komunikasi horizontal yang berlangsung secara bebas ini membentuk karakter karyawan menjadi karakter yang mandiri, memiliki inisiatif dalam bekerjasama dan kreatif.

Hambatan komunikasi horizontal yang masih sering terjadi antara karyawan beretnis Jawa dan karyawan beretnis Tionghoa menunjukkan kesesuaian dengan teori Suranto (2005), yaitu hambatan psikologis berupa perbedaan karakter personal karyawan dan hambatan semantis berupa perbedaan pengguna- 
an bahasa komunikasi yang biasa digunakan. Upaya yang dilakukan oleh karyawan dalam menyelesaikan konflik komunikasi horizontal menunjukan kesesuaian dengan teori Ting-Toomey and Chung (2005), walaupun penyelesaian konflik komunikasi horizontal yang dilakukan baik oleh karyawan beretnis Jawa maupun karyawan beretnis Tionghoa memiliki kesamaan dan perbedaan. Kesamaan upaya penyelesaian konflik oleh karyawan beretnis Jawa dan karyawan beretnis Tionghoa adalah dengan melakukan upaya berkompromi (compromising). Perbedaan upaya penyelesaian konflik terlihat pada upaya kedua apabila upaya awal compromising tidak menghasilkan solusi. Karyawan beretnis Jawa akan berupaya mengintegrasikan (integrating) konflik komunikasi tersebut, karyawan beretnis Tionghoa akan cenderung bersikap menghindari (avoiding).

\section{Simpulan dan Implikasi}

Proses komunikasi horizontal antar karyawan berlangsung dengan baik dan tidak dipengaruhi oleh keragaman karyawan dari segi etnis. Hal tersebut disebabkan adanya peranan pihak manajerial dalam menciptakan sistem yang mendukung proses komunikasi horizontal antar karyawan yang berbeda etnis, serta suasana dan iklim komunikasi horizontal karyawan yang baik. Komunikasi horizontal berlangsung melalui hubungan interpersonal dengan intensitas komunikasi yang tinggi, baik komunikasi bentuk verbal vokal maupun non verbal. Hambatan komunikasi horizontal antar karyawan yang terjadi adalah hambatan komunikasi dari segi psikologi karyawan dan dari segi semantis. Upaya-upaya yang dilakukan oleh karyawan dalam mengatasi konflik komunikasi horizontal adalah dengan melakukan compromising. Namun, karyawan beretnis Jawa cenderung akan melakukan upaya integrating, sedangkan karyawan beretnis Tionghoa cenderung akan bersikap avoiding.

Implikasi penelitian ini menunjukkan bahwa aspek keragaman etnis karyawan tidak mempengaruhi interaksi dan hubungan komunikasi horizontal antar karyawan. Perbedaan karakteristik yang dimiliki oleh setiap karyawan dan intensitas komunikasi yang dilakukan oleh setiap karyawan dapat mempengaruhi interaksi dan hubungan komunikasi horizontal antar karyawan di dalam lingkungan perusahaan.

Pihak manajemen disarankan untuk memberikan perhatian yang lebih baik lagi kepada setiap karyawan, khususnya dalam hubungan dan komunikasi antar karyawan. Pihak manajemen disarankan pula untuk dapat terus meningkatkan iklim perusahaan yang bersifat kekeluargaan, sehingga komunikasi horizontal, hubungan interpersonal dan kerjasama antar karyawan dapat terjalin semakin baik di masa mendatang.

\section{Daftar Referensi}

Christiana, H. (2005). Pengaruh aspek tanggung jawab, status jabatan, wewenang dan kompensasi dalam pengembangan karir terhadap kinerja karyawan etnis Jawa dan etnis Cina (studi kasus pada perusahaan distribusi rokok Djarum PT Lokaniaga Adipermata). Undergraduate thesis. Ilmu Manajemen. Universitas Diponegoro. Semarang

Effendy, O. U. (2007). Ilmu komunikasi, teori dan praktek. Bandung: Rosdakarya.

Griffin, R.W. (2004). Manajemen. Jilid $1.7^{\text {th }} \mathrm{Ed}$. Jakarta: Erlangga.

Kuntjojo. (2009). Metodologi penelitian. Diakses pada tanggal 28 September 2014 dari http://ebekunt.files.wordpress.com/2009/04/met odologi-penelitian.pdf.

Kurniawan, F. (2011). Kompetensi komunikasi antar budaya anggota perkumpulan masyarakat Surakarta etnis Tionghoa dan Jawa. Undergraduate thesis. Ilmu Komunikasi. Universitas Sebelas Maret. Surakarta.

Kusumah, S. D., Marjanto, D. K., Rostiyati, A., \& Ernayanti. (2007). Keragaman budaya. Jakarta: Pusat Penelitian dan Pengembangan Kebudayaan.

Lattimore, D., Baskin, O., Heiman, S. T., \& Toth, E. L. (2010). Public relations: Profesi dan praktik. $3^{\text {rd }}$ Ed. Jakarta: Salemba Humanika.

Marcyola, D. (2013). Iklim komunikasi organisasi dan kinerja karyawan di Bank Bukopin cabang Medan. Undergraduate thesis. Ilmu Komunikasi. Universitas Sumatera Utara. Medan

Marger, M. N. (2006). Race and ethnic relations American and global perspectives. $7^{\text {th }} \mathrm{Ed}$. Jakarta: Penerbit Salemba Empat.

Mathis, R. L. \& Jackson, J. H. (2000). Manajemen sumber daya manusia. $1^{\text {st }}$ Ed. Jakarta: Penerbit Salemba Empat.

Meiliana, D. (2014). Komunikasi internal dalam mempertahankan kinerja karyawan head office PT Dinamika Anak Muda Nasional. Undergraduate thesis. Ilmu Komunikasi. Binus University. Jakarta 
Pakpahan, G. M. (2010). Budaya komunikasi di organisasi dan motivasi kerja karyawan. Undergraduate thesis. Ilmu Sosial dan Politik. Universitas Sumatera Utara. Medan

Palinggi, Y.N. (2013). Manajemen keberagaman karyawan perusahaan. Undergraduate thesis. Ilmu Ekonomi dan Bisnis. Universitas Hasanuddin. Makassar

Paramita, A. \& Kristiana, L. (2013). Teknik focus group discussion dalam penelitian kualitatif. Diakses pada tanggal 1 Oktober 2014. http://ejournal.litbang.depkes.go.id/index. php/hsr/article/viewFile/3301/3292.

Prasidyamurti, H. (2013). Program komunikasi internal perusahaan dalam pengelolaan keragaman budaya (studi program komunikasi internal di Schlumberger Balikpapan dalam mengelola keragaman budaya). Undergraduate thesis. Ilmu Komunikasi. Universitas Gadjah Mada. Yogyakarta.

Setyowati, U. (2013). Kajian semiotika tentang etika komunikasi Anas Urbaningrum dalam pengaruh budaya Jawa. Undergraduate thesis. Ilmu Komunikasi. Universitas Diponegoro. Semarang.
Suranto, A.W. (2005). Komunikasi perkantoran. Yogyakarta: Media Wacana.

Ting-Toomey, S., \& Chung, L. C. (2005). Understanding intercultural communication. Los Angeles, CA: Roxbury Publishing Company.

Warnaen, S. (2002). Stereotip etnis dalam masyarakat multietnis. Yogyakarta: Mata Bangsa.

Wijaya, W. (2014). Human relations tenaga kerja asing dan tenaga kerja lokal di PT Gramitrama Jaya Steel. Surabaya: Agora.

Wursanto, I. G. (2003). Komunikasi organisasi. Yogyakarta: Andi Offset.

Yoshida, S. (2002). Globalization and issues of intercultural communications: Doing successful business in Asia. Diakses pada tanggal 3 September 2014 dari http://marcomm.binus.ac.id/lecturers-journals/ pentingnya-kesadaranantarbudaya-dan-ko mpetensi-komunikasi-antarbudaya-dalamdunia-kerja-global/.

Yvone, S., Krasono, F., \& Suprajitno, S. (2014). Etos kerja pegawai etnis Tionghoa di lima perusahaan keuangan kota Surabaya. Undergraduate thesis. Fakultas Sastra Tionghoa. Universitas Kristen Petra. Surabaya 